\title{
Value Investment Under the Effect of COVID-19
}

\author{
WenLan Fan ${ }^{1, *}, \dagger$ TingGuan $\mathrm{Wu}^{2, *}, \dagger$, Qing Deng ${ }^{3, *, \dagger}$ \\ ${ }^{1}$ Layton House, RDFZ King's College School Hangzhou, 310000, Hangzhou, China. \\ ${ }^{2}$ Dietrich College of Humanities and Social Sciences, Carnegie Mellon University, 15213, Pittsburgh, Pennsylvania, \\ USA \\ ${ }^{3}$ Mandela house, Dulwich international high school Suzhou, 215000, Suzhou, China \\ *Corresponding author. Email: an.wenlan@rkcshz.cn \\ These authors contributed equally.
}

\begin{abstract}
The impact that COVID-19 brought to the global economy has not yet been eliminated, especially for the retailing industry. At this new stage, we apply the value investing method to analyze investment opportunities in the post-epidemic era. [1] This research will use cases from three companies: PepsiCo, Coca-Cola, and Costco, and analyze them quantitatively from three facets: risk, profitability, and market ratios. This paper could help investors clarify their methods of value investment in this special time. And the results indicate that all three companies will attract investors who prefer low risk in investment because three companies are both liquid and have stable profitability growth. But with reference to the market ratios, value investors and momentum buyers may not prefer to invest in any of them. The results show that the risk index of the three companies is similar in terms of risk, and they all have similar beta data. In terms of profitability, coke is the relative best. On the market side, Pepsi is likely to attract more investors because the numbers are better than the other two companies. Based on the data analysis from the three aspects, it is concluded that almost all the investors of the three companies are long-term investors because they can bring a stable income.
\end{abstract}

Keywords: value investment, COVID-19, consumer staples industry, quantitative analysis

\section{INTRODUCTION}

Ever since the stock market has been found, countless investors throw their money into the market. Some of them crave the skyrocket of their assets, so they speculate for short-term returns. While some other investors look at the long run, investing for the true values hidden inside of companies. But greed still drives people crazy from time to time. A huge financial crisis happens even before our financial system becoming mature. From 17th-century Dutch tulip mania, the 18th century South Sea bubble, to the Wall Street crash of 1929 , the Japanese property bubble of the 1980s, the crash of the dot-come bubble in 2000-2001, and the now deflating United States housing bubble, speculation has dominated the market, misleading investors to the financial crush. [2] However, to achieve the steady growth of wealth, value investment is the wise strategy we want to apply to prevent the risk brought by speculation and the effect of short-term market fluctuation.
The value investment strategy is initially brought forward in the book Security Analysis by Benjamin Graham, indicating the intrinsic value of companies determine the price of the stock Because the stock price is only influenced by the financial performance of the company, rather than the market news, government policies, or emotion of investors. Besides, the other principle for value investment is to select companies where their stock prices are lower than their intrinsic values. In this way, the safety boundary turns out to be positive, and investors can also have a positive return for their investment. According to Guolu Qiu, the power of value investment comes from two aspects: firstly, due to the panic market atmosphere, the constant drop of stock prices leads to the undervaluing of intrinsic values of companies; secondly, some good firms are capable of constantly creating values, which makes them grow larger. [3] And in the recent industrial development, more and more high-tech companies enter the financial market, such as chip-production and e-communication. The in-depth value investment strategy has broader applications. Some methods focus on the dividend of 
companies, some focus on the long-run cash flow, and some focus on the future development of certain industries.

In conclusion, it can be found that the researches on value investment theory in existing literature mostly take enterprises and big data as the research objects under normal economic conditions. However, there are few studies on the background of COVID-19, and the research on the consumer staples industry is relatively weak. As a result, this paper mainly studies the impact of COVID-19 on enterprises and the selection criteria of long-term investors for investment enterprises. The enterprises we choose are mainly based on the consumer staples industry, and the three enterprises we choose are Coca-Cola, Pepsico, and Costco Wholesale.

\section{DATA AND METHOD}

We select the data mainly from yahoo finance and each company's annual reports from the income statement, balance sheet, and cash flow statement from 2015 to 2020 . Our data includes stock and finance data, such as stock price, market capitalization, net profit, market value, return on equity, net asset value per share, earnings per share, etc.

\section{1 data}

The Coca-Cola Company is a full-category beverage company, offering more than 500 brands in more than 200 countries and regions worldwide. In addition to Coca-Cola, the Coca-Cola Company's globally valuable beverage brands include Ayatore Green Tea, Costa Coffee, Del Valle Juice, Fanta, Choa coffee, Minute Maid Juice, Sprite, and ZICO Coconut Water. From reducing sugar in drinks to introducing innovative products, the company's product portfolio continues to evolve. [4] Coca-Cola is committed to reducing its impact on the environment by promoting water feedback and packaging recycling. The Coca-Cola Company and its bottling partners employ more than 700,000 people and drive the economic development of communities worldwide. [5]

The company PepsiCo, in 1965, was a single company delivering perfectly salty snacks served alongside the best cola on earth. Their vision led to what quickly became one of the world's leading food and beverage companies: PepsiCo. PepsiCo products are enjoyed by consumers more than one billion times a day in more than 200 countries and territories worldwide. PepsiCo generated more than $\$ 70$ billion in net revenue in 2020, driven by a complementary food and beverage portfolio that includes Frito-Lay, Gatorade, Pepsi-Cola, Quaker, Tropicana, and Soda Stream. PepsiCo's product portfolio includes a wide range of enjoyable foods and beverages, including 23 brands that generate more than $\$ 1$ billion each in estimated annual retail sales.
Costco, in full Costco Wholesale Corporation, American operator of discount stores of the type known as warehouse clubs or wholesale clubs, in which bulk quantities of merchandise are sold at deeply discounted prices to club members who pay an annual membership fee. It is one of the largest retailers in the world. Costco traces its history back to 1976, when Sol Price, a pioneer in warehouse club retailing, opened the first Price Club in San Diego. Jeffrey H. Brotman and James D. Sinegal opened the first Costco in Seattle in 1983. The Price Company (corporate parent of Price Club) and Costco merged in 1993 to become Price/Costco. In the early 21 st century, the company operated stores in the United States, Canada, Mexico, Europe, the Far East, and Australia.

\section{2 method}

. $\mathrm{PE}$ ratio: The price-to-earnings ratio $(\mathrm{P} / \mathrm{E}$ ratio) is a valuation metric used by investors to know whether a stock is over- or undervalued [6]. [7]

$\mathrm{P} / \mathrm{E}$ Ratio= Earnings per share /Market value per share

PEG ratio: The PEG ratio is used to determine a stock's value while also factoring in the company's expected earnings growth. It is thought to provide a more complete picture than the more standard $\mathrm{P} / \mathrm{E}$ ratio.

Price/earnings to growth ratio (PEG ratio) is a stock's price-to-earnings $(\mathrm{P} / \mathrm{E})$ ratio/growth rate of its earnings for a specified period.

Current ratio: The current ratio is a liquidity ratio that measures a company's ability to pay short-term obligations or those due within one year.

Equation: Current Ratio $=$ Current assets/current liabilities.

Quick ratio: The quick ratio is an indicator of a company's short-term liquidity position and measures its ability to meet its short-term obligations with its most liquid assets.

\section{$\mathrm{QR}=\mathrm{CE}+\mathrm{MS}+\mathrm{AR}$ dividend by $\mathrm{CL}$}

Remarks: QR: quick ratio, CE: cash and equivalents. MS: marketable securities, AR: accounts receivable, CL: current liabilities.

ROA: Return on assets is a profitability ratio that provides how much profit a company can generate from its assets.[8]

Equation: $\mathrm{ROA}=$ Net Income/ average total assets.

ROE: Return on equity (ROE) is a ratio that provides investors with insight into how efficiently a company (or, more specifically, its management team) is handling the money that shareholders have contributed to it. [9] 
Equation: ROE= Net Income / shareholder equity

Beta: The beta of a company measures how the company's equity market value changes with changes in the overall market.

Market capitalization: Market capitalization refers to the total dollar market value of a company's outstanding shares of stock.

Equation: it is calculated by multiplying the total number of a company's outstanding shares by the current market price of one share.

Profit margin: Profit margin is one of the commonly used profitability ratios to gauge the degree to which a company or a business activity makes money. It represents what percentage of sales has turned into profits. [10][11]

Total assets turnover is defined as the ratio between net income and total average assets, or the amount of financial and operational income a company receives in a financial year compared to the average of that company's total assets.[12]

Momentum: Momentum is the rate of acceleration of a security's price - that is, the speed at which the price is changing. Market momentum refers to the aggregate rate of acceleration for the broader market as a whole.

Debt ratio: The debt ratio is a financial ratio that measures the extent of a company's leverage. [13]

Equation: Debt ratio $=$ Total debt $/$ total assets

(13) Debt/asset ratio: It is the ratio of the company's total debt to the total assets of the company; this ratio represents the ability of a company to have the debt and raise additional debt if necessary for the operations of the company.

Equation: Debt/ total asset

\section{RESULTS AND DISCUSSION}

\subsection{PepsiCo}

\subsubsection{Risk}

PepsiCo is a relatively large company in the consumer staple industry with its over 200 million market capitalization. So, it is usually safer to invest in large than in small, as it is less possible for a huge company like PepsiCo to go bankrupt in the short term. Besides, PepsiCo's debt/asset ratio is also smaller than 1, proving its low risk for investment as PepsiCo has enough assets to deal with liquidity problems. The beta for PepsiCo is also much smaller than 1, again proving its lower risk for investment than that of average in the stock market.[14]

\subsubsection{Profitability}

However, the COVID-19 has a severe impact on the profitability of PepsiCo, closing countless offline stores and preventing people from buying PepsiCo's beverages in the vending machines. Its net profit margin is only around $10 \%$, and its ROA is also smaller than $10 \%$. Plus, PepsiCo's asset utilization is not excellent because its asset turnover ratio is only smaller than 1. But still, PepsiCo is making a stable profit from year to year, which might attract some investors who pursue lower returns with lower risk.

\subsubsection{Market ratios}

With references to various market ratios, there are some worth notice. The momentum investor would probably be inclined to invest in PepsiCo as the company's recent performance is better than the index of Dow Jones - it has momentum, even under an environment where most investors are not optimistic. Nonetheless, PepsiCo's PE and PEG ratios are too high to attract some value investors or growth investors. But for long-term investors, can expect a recovery for Pepsico after the pandemic and buy the shares at nowadays low stock price.

\subsection{Coca-cola}

\subsubsection{Risk}

Firstly, referring to risky, we can compare the different ratios to see the different firms' risk levels, such as beta, current ratio, quick ratio. And use market capitalization, cash levels, and total debt and assets to compare different firms' sizes. For market capitalization, Coca-Cola has 235.78B. The current ratio is better than 1, which means it can pay back its debts. And Coca-Cola has a ratio of 1.33 , which is over 1 , which means that they may not pay back their liabilities on time if they have some emergencies. Referring to quick ratio is the ratio minus inventory. And Coca-Cola also has a quick ratio of over 1 , about 1.13 means they don't have much inventory. Beta means risk. Coca-Cola has the highest risk, about 0.61.[14]

\subsubsection{Profitability}

Referring to profitability, we can use various ratios and data to compare different firms their profitability level, whether they can earn more profit and give their shareholders high-profit revenue. We can use ratios such as total assets turnover, profit margin, ROA, ROE, and net income. A higher profit margin means it can earn more profit from their single product, and Coca-Cola has the highest profit- margin of about $21.59 \%$. Coca-Cola has a ROA ratio of about $6.96 \%$. For the ROE ratio, this index reflects the level of return on 
shareholders' equity and measures a company's efficiency using its own capital. The higher the index value, the higher the return on the investment. For the ROE ratio, Coca-Cola has a figure of $34.73 \%$.

\subsubsection{Market ratios}

Finally, we also use the market value relationship to find each firm's value. Like stock price, PB value, price/book value, dividend yield, PRG, and whether it is momentum. For the stock price, Coca-Cola has a value of about 54.56. regarding dividend yield, the dividend yield is an estimate of the only dividend return on a stock investment. Coca-Cola has the highest dividend yield, about $3.23 \%$.

\subsection{Costco}

\subsubsection{Risk}

Costco has a very large market capitalization, so it is relatively safe to invest as they have many loyal consumers, and also, they are not easy to go bankrupt in the short term. Costco's current ratio is 0.99 , which is close to 1 , which means it has a good solvent ability. Additionally, Costco's ratio of total debt / total assets is very low, which means Costco has sufficient capital and has a low possibility that the enterprise cannot repay the debt. The beta shows that the risk of investing in Costco is lower than the average stock in the market. The beat data shows the risk of invest Costco is much lower than other companies. [14]

\subsubsection{Profitability}

The net profit margin of Costco is very low because the COVID-19 was very serious in the last year. However, Costco has a great difference between the current ratio and the quick ratio. This data means Costco may have a great number of inventories in its asset.

\subsubsection{Market ratios}

The PE ratio is higher than 20, and the PEG ratio is 2.72, which shows that the stock is priced above its actual price and is not considered a growth stock. But Costco still makes a profit year by year.

In conclusion, On the risk side, the market capitalization for PepsiCo, Coca-Cola \& Costco is 205.269 billion,235.78billion, and173.32 billion. The debt ratio for PepsiCo and Costco are $0.74 \& 0.18$. To Coca-Cola, it has a quick ratio of 1.33 and a current ratio of 1.33. In the beta, for PepsiCo is 0.61 , for Coca-Cola is 0.61 and for Costco is 0.61 .

On the profitability side, the net profit margin for these three companies is $10.58 \%, 21.59 \% \& 2.53 \%$. And also, they have $8.56 \%, 6.96 \% \& 24.93 \%$ for their ROA ratio. Coca-Cola has an $\mathrm{ROE}$ ratio of $34.73 \%$.

On the market ratio side, PepsiCo and Costco have PE ratios of $27.42 \& 32.9$ and PEG ratios of $3.23 \&$ 2.72. For Coca-Cola, it has a dividend yield of about $3.23 \%$.

\section{CONCLUSION}

PepsiCo, Coca-Cola, and COST are making a stable profit from year to year, and this characteristic might attract some investors who do not prefer high risk for their investment and long-term investor. Nonetheless, PepsiCo, Coca-Cola, and Costco have higher than 20 for their PE ratio and around 3 for their PEG ratio, which might not attract some value investors or growth investors. And with reference to the market ratios, the momentum investor would probably want to invest in PepsiCo as the company's recent performance is better than the index of Dow Jones.

According to the asset turnover ratio of Pepsi is 0.81 , which is relatively low. We can conclude from this that the resource utilization rate of Pepsi is lower than that of other enterprises. Therefore, my suggestion is to integrate resources to avoid resource waste and improve the production efficiency of individual products to reduce the average cost per unit.

For Costco, the membership system is the most important source of profits they earn. However, the current business model makes Costco popular in the United States. However, when it comes to expanding the overseas market, I suggest that Costco pay more attention to the differences in the market conditions of different countries. The high-priced membership system that is popular in the United States may not be suitable for undeveloped markets such as China.

Unlike Pepsi, there is no so-called era filter in consumer psychology for Coca-Cola. I suggest marketing should enhance the concept of Coca-Cola in the minds of consumers while investigating the needs and tastes of different groups to increase loyal consumers. Through these operations to increase sales and total business volume.

The research conclusions of this paper, on the one hand, have a certain theoretical expansion of the research object and background of value investment, that is, under the background of COVID-19, and the consumer industry as the research object of value investment theory research; On the other hand, in practice, how to improve the competitiveness of enterprises in the consumer industry and it has a certain practical significance for the investment of investors. 


\section{REFERENCES}

[1] Chunding Li and Hanwen Zhang, "The employment and economic growth effects of the global spread of the new crown epidemic." International economic and trade exploration 37.07(2021):4-19. doi:10.13687/j.cnki.gjjmts.2021.07.001.

[2] En.wikipedia.org. 2021. Financial crisis - Wikipedia. [online] Available at: <https://en.wikipedia.org/wiki/Financial_crisis> [Accessed 2 August 2021].

[3] Ping Yu, and Jing Li. "Market value investment strategy research on valuation indicators and fundamental indicators." Accounting Newsletter 9:5

[4] Timmis Kenneth." COVID-19 transmission: economy-boosting investment should target innovation in pandemic containment strategies to minimize restrictions of civil liberties." Environmental Microbiology 22.11(2020): doi:10.1111/1462-2920.15263.

[5] Lingzhi Liu, Mengwei Shi, and Bangming Xiao. "Impact of the new crown outbreak on consumers' choice of purchasing channels," Journal of China Agricultural University 26.07(2021):272-284. doi:CNKI:SUN:NYDX.0.2021-07-027.
[6] Ruirui Ma, Zhenbaodao Pharmaceutical Profitability Analysis and Promotion Strategy Research.2021. Yunnan Normal University, MA Thesis.

[7] Ya Xiao, "PE Valuation And PB Valuation Analysis Based On Banking." TIME Finance 000.005 (2012): 254-254.

[8] Jing Cai, Relationship between corporate financing, diversification strategy and return on assets.2020. Zhejiang University, MA Thesis.

[9] Shujun Chen, Market Valuation Differences and China Stock Return Study.2019. Southwest University of Finance and Economics, MA Thesis.

[10] Ying Sun, APT Model Stock Valuation and Effectiveness Research based on Industry Price/Earnings Ratio.2017. South C

[11] Li Xing, Environmental regulation on the impact of corporate profit margins and mechanism analysis.2020. Jinan University, MA thesis.

[12]Wenjing Wang, Benchmark Yield Study for Wind Power Investment Projects.2017. North China Electric Power University (Beijing), MA thesis.

[13] Qin Liu, The optimization study of asset allocation of life insurance companies under the second generation guideline.2020. Qingdao University, MA thesis.

[14] Shen Liu, TJ Technology Company Financial Risk Evaluation and Control Research.2020 